\title{
Computer Assisted Project-Based Instruction: The effects on Science Achievement, Computer Achievement and Portfolio Assessment
}

\author{
Yavuz Erdoğan \\ Assoc. Prof., Marmara University, Turkey, yavuz.erdogan@marmara.edu.tr \\ Dinçer Dede \\ Teacher, Ministry of Education, Turkey, dincerdede@yahoo.com
}

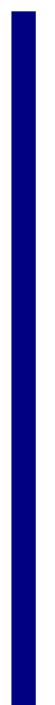

The purpose of this study is to compare the effects of computer assisted projectbased instruction on learners' achievement in a science and technology course, in a computer course and in portfolio development. With this aim in mind, a quasiexperimental design was used and a sample of 70 seventh grade secondary school students from Org. Eşref Bitlis Primary School in Istanbul was selected. The students were randomly assigned to one of the two groups: the control group and experimental group. Instruction to control group was provided by the traditional project-based learning approach, to the experimental group was provided computer assisted project-based learning approach. Both groups were given instruction on the topic of Our Living Conditions in the syllabus of 7 th grade Science and Technology course. During the five-week instruction, experimental group was required to prepare the projects with using computer assisted project-based method, while control group used traditional project-based method. At the end of the study, the findings revealed that science and technology and portfolio assessment scores of the experimental group were significantly higher than that of the control group. This result indicates that the learning gains are higher when instruction is provided by computer assisted project-based instruction than by the traditional method.
\end{abstract}

Key Words: project, project-based instruction, computer assisted project-based instruction, portfolio, Science and Technology Courses

\section{INTRODUCTION}

One of the instructional methods which could be regarded as an alternative to traditional teaching methods and in which the learner is central to the learning process is projectbased instruction. Integrating project-based instruction into a curriculum provides students with real world problem solving investigations, allows students to work independently and reveals realistic products (Kafi and Motallebzadeh, 2014). Projectbased learning allows students to gain a deeper understanding of materials when they actively construct their understanding by working with and using ideas (Hsu, Dyke, Chen and Smith, 2015). Researches states that project-based learning enables students to

DOI: $10.12973 / \mathrm{iji} .2015 .8214 \mathrm{a}$ 
demonstrate better problem solving skills (Finkelstein, Hanson, Huang and Huang, 2010) and that students also show improved critical thinking skills (Beckett and Miller, 2006). Summers and Dickinson (2012) argued that when project-based instruction was properly implemented, it often produced dramatic achievement gains and deep conceptual understanding. In project-based instruction classrooms, students demonstrate improved attitudes toward learning. They exhibit more engagement, are more self-reliant and have better attendance than in more traditional settings (Mohsena, Abodlvahedb and Wan, 2015; Walker and Leary, 2009).

At the core of project-based instruction are the projects prepared by the learners. A project requires a design or design development, imagination and planning. The basic characteristic of a project is the learner's ability to decide independently on how and in which order the problem at hand could be solved (Kubinova, Novotna and Littler, 1998). Thereby, learners try to find solutions to the problems they are presented with either individually or in groups. Through projects, learners can work individually to structure their knowledge and finalize their work realistically and present their own products in accordance with concepts and scientific principles (Cole, Means, Simkins and Tavali, 2002).

According to Manson and Bramble (1997) it is as much important to increase student interest in school by creating a learning environment where various disciplines are linked together as it is important to teach particular disciplines. This point of view has led to the emergence of project-based instruction as the project development process became a part of the classroom. In project-based instruction, while the learners prepare their projects in groups with intra-group collaboration, the teacher guides the learners by observing the learners' project development processes in and out of the classroom. In project-based instruction, learners work together on a real issue or problem from a variety of disciplines and finalize their projects with a presentation (McGrath, 2002; Wolk, 2001). Via project-based learning, learners create associations between various courses such as mathematics, social sciences, literature and physics in order to find answers to open-ended questions and thereby are more enthusiastic to learn (Curtis, 2002). Learners find the necessary information on their own to carry out their projects and present a product in the end through creating associations among various types of information they have obtained.

Due to the fast growth of information and communication technologies, the use of technological facilities at school and in the classroom has become inevitable. The use of technologies in teaching and learning provides the learners with richer learning environments, creates interest and helps increase motivation through a student-centered approach (İşman, Baytekin, Balkan, Horzum and Kıyıc1, 2002). When learners are willing to understand and to succeed in a subject area, they can, thus, learn much easily. In this respect, the use of technologies plays an important role in the learning-teaching process (İşman, Baytekin, Horzum and Kıyıc1, 2002). The opportunities offered by the computer technologies for the teaching process improves the quality of education. However, technologies can only support learning should they be used in relation to appropriate teaching and learning theories. For instance, multi-dimensional learning 
outcomes could be obtained when traditional project-based instruction is integrated with the basic principles of learning theories of technology and constructivism (Muniandy, 2000). As a result, the idea of computer assisted project-based instruction was suggested. In such a teaching and learning context learners design and make decisions on their own learning and consequently enhance their creativity and they collaboratively try to solve the problems they encounter. It is a technology based learning situation where learners evaluate their success, where real life is brought into classroom and where parents are actively involved in the learning process (Erdem, 2002).

It has also been suggested that the quality of education could be enhanced by using computers in the project development process. Various opportunities provided to learners through technologies stimulate learners to follow and attend to their own interests. Liu, Hsieh, Cho and Schallert (2006) found that students had a better understanding of science concepts and felt more confident about being successful learners after they completed a computer assisted project-based learning unit. The use of computers in project-based instruction influences learners' achievement of target behaviours and portfolio development in a positive way.

In the last decade, computer assisted project-based learning has been widely applied in science classrooms to support students' development of deeper understanding of science concepts ideas (Fogleman, McNeill and Krajcik, 2011). Hsu, Dyke, Chen and Smith (2015) claimed that computer assisted approach was effective in improving learning outcomes and developing their science knowledge. Also experiencing computer assisted project-based learning, students were apparently more positive in science attitude (Lai, 2013). Considering all of the above, the present paper aims to compare the effects of computer assisted project-based instruction and traditional project-based instruction on learners' achievement levels in a science and technology course, in a computer course and in portfolio assessment. With these aims in mind, the following hypotheses were tested;

1. In the experimental group, where computer assisted project-based instruction is used, learners' achievement scores in the science and technology course will be significantly higher than the learners' achievement scores for the same course in the control group, where traditional project-based instruction is used.

2. In the experimental group, where computer assisted project-based instruction is used, learners' achievement scores in the computer course will be significantly higher than the learners' achievement scores for the same course in the control group, where traditional project-based instruction is used.

3. In the experimental group, where computer assisted project-based instruction is used, learners' portfolio assessment scores will be significantly higher than the learners' portfolio assessment scores of the control group, where traditional projectbased instruction is used.

\section{METHOD}

Research Model 
In this study, a quasi-experimental design was used and the students were randomly assigned to control and experimental groups. Instruction to the control group was provided by the traditional project-based learning approach, to the experimental group using computer assisted project-based learning approach.

\section{Participants}

Purposive sampling was used to select a sample of 70 seventh grade students from Org. Eşref Bitlis Primary School in Istanbul and randomly assigned 35 each into experimental and control group. $57.1 \%$ of the sample was female $\left(\mathrm{N}_{\text {female }}=40\right)$, while $42.9 \%$ was male $\left(\mathrm{N}_{\text {male }}=30\right)$. The willingness of the teachers and the administration to collaborate with the researcher, their interest and readiness to contribute to scientific knowledge and the school's technological equipment were the main reasons in the selection of Org. Eşref Bitlis Primary School as the field of study.

\section{Procedure}

Initially, project-based teaching activities were prepared on the "Our Living Conditions" topic of 7th grade science and technology course to be used for the control group. For this stage, learners were briefed on the necessary information and activities in relation to the "Our Living Conditions" topic of 7th grade science and technology course which was organized around project-based instruction. They were also informed on how these information and activities were structured which were then gradually explained. In line with a teaching plan, sub-topics were introduced to the control group in due course. At the end of the lesson, learners were asked to brainstorm about the type of product that could be prepared in relation to the topic. Learners were assigned to prepare a portfolio and bring it to the next lesson.

For the experimental group, sub-topics were introduced in due course in line with the teaching plan. At the end of the lesson, learners were asked to brainstorm about the type of product that could be prepared in relation to the topic and they were, then, taken to the Information Technologies classroom to prepare a portfolio at the computer. After all the topics were covered, learner products were presented to the class and a Science Achievement Test, a Computer Achievement Test, a Portfolio Evaluation Form and a Peer Evaluation Form were administered by the researchers. While the learners of the control group presented their projects in the classroom, learners of the experimental group did their presentations in the information technologies classroom.

\section{Instruments}

Four different tools were employed for data collection purposes: a science achievement test, a computer achievement test, a portfolio assessment form and a peer assessment form. These data collection instruments are explained in detail below.

\section{Science Achievement Test}

The test was developed by the researchers in order to assess the students' achievement of the subject matter. The multiple-choice test consisted of 25 questions and the validity and reliability studies of the test were carried out by the researchers. The questions were 
ensured to subsume and exemplify the content of the unit in order to establish content validity of the achievement test. For the item analysis; item-total and item-reminder correlations, item difficulty and item discriminating power analyses were carried out.

The value of item difficulty was computed for each item, where the value of item difficulty was greater than $80 \%$, those items were rejected, because they were very easy item. Therefore, the $1^{\text {st }}$ and $22^{\text {nd }}$ items 22 were rejected. Similarly, the item having the item difficulty value less than $20 \%$ were also rejected on account of being difficult items. Therefore, the $17^{\text {th }}$ item was rejected. The reliability analysis was then carried out with the remaining 22 questions, and the Kuder-Richardson reliability coefficient was found to be 0.75 .

\section{Computer Achievement Test}

The computer achievement test was developed by the researchers in order to determine the students' achievement in the subject matter. It is a multiple-choice test consisting of 25 questions. The validity and reliability studies of the test were carried out again by the researchers. After the item analysis the $2^{\text {nd }}$ item was removed from the test as its item discrimination value was too low. At the end of the reliability analysis administered with the remaining 24 questions, the Kuder-Richardson reliability coefficient was found to be 0.70 .

\section{Portfolio Assessment Form}

Two different Portfolio Assessment Forms were designed regarding the different contexts of portfolio development; one for the traditional project-based instruction and one for the computer assisted project-based instruction. The form for traditional method was designed by the researchers and special attention was paid to the selection of topics from the "Our Living Conditions" unit for the $7^{\text {th }}$ grade students; topics which would arouse interest, would create motivation and were suitable for the learners to do research on were selected. For the computer assisted project-based method, Intel Education for the Future Portfolio Assessment Scale was used (Candau, Dohety, Yost and Kuni, 2002). Higher-order intellectual skills which were expected to be observed at the end of the intervention were specified and their appropriateness to the program objectives was taken into consideration.

\section{Peer Assessment Form}

In order to involve learners in the assessment and evaluation of their own projects a Peer Assessment Form was prepared. In the design of the form, Intel Portfolio Assessment Scale was used as an example. Using the peer assessment form, learners carried out ingroup evaluations. Special attention was paid to ensure that the items in the form were clear, mono-dimensional and non-influential. Experts' views from the Department of Computer and Instructional Technology were also gathered before finalizing the form. Learners were advised to provide true and realistic answers in completing the form. It was also underlined that they should not be biased in evaluating their peers' projects.

Data Analysis 
Before hypothesis testing, Kolmogorov-Smirnov normality test was applied to verify normal distributions of the variables considered. Both science achievement test and computer achievement test scores have shown normal distribution $(z=0.85 ; p>.05$ and $\mathrm{z}=1.15 ; \mathrm{p}>.05)$. Thus, in order to compare the science achievement and computer achievement of two groups the parametrical methods namely independent samples t-test was conducted. For the comparison of portfolio assessment results non-parametric statistics, namely Mann-Whitney U test was administered. For the statistical tests $p<.05$ value was accepted as the significance threshold level.

\section{RESULTS}

In this section, the results of the experimental group, which used computer assisted project-based instruction (CA-PBI), and the control group, which used traditional project-based instruction (T-PBI) are compared in relation to the learners' science and technology course achievement scores, computer course achievement scores and portfolio assessment scores.

Table 1: A Comparison of Learners' Science and Technology Course Achievement Posttest Scores in terms of Teaching Method Using Independent Samples t-Test

\begin{tabular}{|c|c|c|c|c|c|c|}
\hline Teaching Method & $N$ & Mean & $s s$ & $s d$ & $t$ & $p$ \\
\hline CA-PBI & 35 & 12.43 & 3.97 & \multirow{2}{*}{68} & \multirow{2}{*}{5.21} & \multirow{2}{*}{$\begin{array}{c}0.00 \\
0\end{array}$} \\
\hline T-PBI & 35 & 7.94 & 3.19 & & & \\
\hline
\end{tabular}

As presented in Table 1, the mean value for the science and technology course achievement of the group which used computer assisted project-based instruction (CAPBI) was 12.43 , while the mean value for the same course of the group which used traditional project-based instruction (T-PBI) was 7.94. The results of the independent samples t-test administered to test the effect of the teaching method variable indicated that science and technology course academic achievement scores of the learners who received computer assisted project-based instruction was higher at .05 level than the learners who received traditional project-based instruction $(t=5.21 ; \mathrm{p}<.05)$.

Table 2: A Comparison of Learners' Computer Course Achievement Posttest Scores in terms of Teaching Method Using Independent Samples t-Test

\begin{tabular}{lcccccc}
\hline Teaching Method & $N$ & Mean & ss & sd & $t$ & $p$ \\
\hline CA-PBI & 35 & 14.80 & 2.39 & & & 0.07 \\
\cline { 1 - 5 } T-PBI & 35 & 13.51 & 3.41 & & 1.83 & 2 \\
\hline
\end{tabular}

As illustrated in Table 2, the mean value of computer course achievement scores for the learners in the experimental group was 14.80, while the mean value for the control group was 13.51. Computer course achievement scores of the experimental and control groups were compared in terms of the teaching method using an independent samples ttest. The test results did not indicate any statistically significant difference between the two groups $(\mathrm{t}=1.83 ; \mathrm{p}>.05)$. 
Table 3: A Comparison of Learners' Portfolio Assessment Posttest Scores in terms of Teaching Method Using Mann-Whitney U Test

\begin{tabular}{|c|c|c|c|c|c|}
\hline Teaching Method & $N$ & Mean Rank & Sum of Ranks & $U$ & $p$ \\
\hline CA-PBI & 35 & 43.28 & 1514.50 & \multirow{2}{*}{340.50} & \multirow{2}{*}{$\begin{array}{c}0.00 \\
1\end{array}$} \\
\hline T-PBI & 35 & 27.73 & 970.50 & & \\
\hline
\end{tabular}

Portfolio assessment scores of the two study groups were compared using a MannWhitney $U$ test as shown in Table 3. As the results indicate, the mean rank for the learners in the experimental group was 43.28 and for the learners in the control group it was 27.73. The results of the Mann-Whitney $U$ test, which was administered to test the effect of the teaching method, indicated that portfolio development scores of the experimental group learners were significantly higher than that of the control group learners $(\mathrm{U}=340.50 ; \mathrm{p}<.05)$.

\section{DISCUSSION}

This paper compared the effects of two strategies, computer assisted project-based instruction and traditional project-based instruction, on learners' achievement scores in a science and technology course, in a computer course and in portfolio development. The findings of the study indicated that the science achievement scores of the group that received computer assisted project-based instruction were significantly higher than that of the control group which received traditional project-based instruction $(t=5.21 ; \mathrm{p}<.05)$.

Project-based learning has shown to be more effective than traditional methods for teaching maths, economics, language, science and other disciplines (Baş, 2011; Baş and Beyhan, 2010; Beckett and Miller, 2006). The most important factor that could explain why the learners in the group that received computer assisted project-based instruction were more successful was that learners were able to have meaningful hands-on experience via the creative pictures, videos and other multimedia materials they designed at the computer (Blumenfeld, Karjcik, Marx and Soloway, 1994; Simkins, Cole, Tavalin and Means, 2002).

Besides the use of computers in the project development process plays a complementary role and shares the hard job of other elements in the teaching system such as books, friends and teachers and thus facilitates long-term retention of the topics (İssman, Baytekin, Balkan, Horzum and Kıyıcı, 2002; Özmen, 2004; Yalın, 2002). Learners are more successful when they are much more motivated to learn as they find the context of computer assisted project-based instruction interesting and as they become curious about the tools (Cole, Means, Simkins, and Tavali, 2002; Frank and Barzilai, 2004, Greenbowe, Burke and Windschitl, 1998; Jackson and Songer 2000; McGrath, 2002; Melograno, 2006; Wolk, 2001). Therefore, to ensure that meaningful learning takes place and more specifically to teach subjects which learners' have difficulties in understanding such as sciences, the use of multimedia assisted teaching activities could have had a positive effect on the achievement scores of the learners in the group which 
received computer assisted project-based instruction (Hsu, Dyke, Chen and Smith, 2015; Harwood and McMahon, 1997; Lai, 2013).

Furthermore, portfolio development scores of the learners' in the group which received computer assisted project-based instruction were observed to be significantly higher than the scores of the learners' in the group which received traditional project-based instruction ( $\mathrm{U}=340.50 ; \mathrm{p}<.05)$. Results of similar research also provide support for this finding (Frank and Barzilai, 2004; Melograno, 2006; Thomas, 2000). Learners' portfolio development scores were observed to be influenced by the opportunities provided via various software and technologies used as part of computer assisted project-based instruction such as a ready-made portfolio template, a dictionary of spelling for spelling mistakes and motion pictures and animations found in software libraries (Blumenfeld, Karjcik, Marx and Soloway, 1994; Simkins, Cole, Tavali and Means, 2002). Besides, the use of technologies in the computer assisted project-based instruction process positively effects learners' attainment of the target aims and their portfolio development (Hsu, Dyke, Chen and Smith, 2015; Melograno, 2006). Learners tend to find the technological context interesting and become curious about it. This could, then, increase their willingness to learn and thus their success at portfolio development (Frank and Barzilai, 2004; McGrath, 2002; Melograno, 2006; Wolk, 2001). This could be a possible interpretation of why the portfolios developed via computer assisted project-based instruction were scored higher than the ones developed via traditional project-based instruction.

However, there was no significant difference between the computer achievement scores of the learners in experimental and control groups $(t=1.83 ; p>.05)$. 7th grade learners are introduced to computer technologies such as word processing, presentation and publishing software gradually from 4th, 5th and 6th grades. Therefore 7th grade learners that composed both the study groups were likely to be familiar with the computer technologies, such as presentation, publishing and word processing software, used in the research. Consequently, it is possible to argue that learners' familiarity with computer technologies could explain why there was no significant difference between the learners' computer achievement scores.

\section{REFERENCES}

Baş, G. (2014). Investigating the effects of project-based learning on students' academic achievement and attitudes towards English lesson. The Online Journal of New Horizons in Education, 1(4), 1-15.

Baş, G. and Beyhan, Ö. (2010). Effects of multiple intelligences supported projectbased learning on students' achievement levels and attitudes towards English lesson. International Electronic Journal of Elementary Education, 2(3), 365-386.

Beckett, G. H. and Chamness, M. P. (2006). Project-based second language and foreign language education: Past, present, future. Greenwich, Connecticut: Age Publishing. 
Bloom, A. (1987). The closing of the American mind, simon and schuster. United States of America: State University of New York Press.

Blumenfeld, P. C., Karjcik, J. S., Marx, R. W. and Soloway, E. (1994). Lessons learned: How collaboration helped middle grade science teachers learn project-based learning. The Elementary School Journal, 94 (5), 539-551.

Candau, D., Dohety, J., Yost, J. and Kuni, K. (2002). Intel teach to the future with support from Microsoft: professional development curriculum and CD-ROM. California Intel Corporation.

Cole, K., Means, B., Simkins, M. and Tavali, F. (2002). Increasing student learning through multimedia projects. Alexandria, VA: Association for Supervision and Curriculum Development.

Curtis, D. (2002). The power of projects. Educational Leadership, 60 (1), 50-53.

Erdem, M. (2002). Proje tabanlı öğrenme. Hacettepe Üniversitesi Eğitim Fakültesi Dergisi, 22, 172-179.

Finkelstein, N., Hanson, T., Huang, C.W., Hirschman, B. and Huang, M. (2010). Effects of problem-based economics on high school economics instruction. Washington, DC: Department of Education, Institute of Education Sciences.

Fogleman, J., McNeill, K. L. and Krajcik, J. (2011). Examining the effect of teachers' adaptations of a middle school science inquiry-oriented curriculum unit on student learning. Journal of Research in Science Teaching, 48(2), 149-169.

Frank, M. and Barzilai, A. (2004). Integrating alternative assessment in a project-based learning course for pre-service science and technology teachers. Assessment \& Evaluation in Higher Education, 29 (1), 41-61.

Greenbowe, T., Burke, K.A. and Windschitl, M. (1998). Developing and using computer animations for chemistry instruction. Journal of Chemical Education, 75 (12), 1658-1661.

Harwood, W.S. and McMahon, M.M. (1997). Effect of integrated video media on student achievement and attitudes in high school chemistry. Journal of Research in Science Teaching, 34 (6), 617-631.

Hsu, P.S., Dyke, V.M., Chen, Y. and Smith, T.J. (2015). The effect of a graph-oriented computer-assisted project-based learning environment on argumentation skills. Journal of Computer Assisted Learning, 31 (1), 32-58.

İşman, A., Baytekin, Ç., Balkan, F., Horzum, B. and Kıyıcı, M. (2002). Fen bilgisi eğitimi ve yapısalcı yaklaşım. The Turkish Online Journal of Educational Technology, 1 (1), 41-47.

Jackson, M.M. and Songer, N.B. (2000). Student motivation and internet technology are student empowered to learn science. Journal of Research in Science Teaching, 37, 459 479. 
Kafi, Z. and Motallebzadeh, K. (2014). A flipped classroom: Project-based instruction and 21st century skills. International Journal of Language Learning and Applied Linguistics World, 6 (4), 35-46.

Kubinova, M., Novotna, J. and Littler, G.H. (1998). Projects and mathematical puzzles, a tool for development of mathematical thinking. European Research in Mathematics Education, 5 (1), 53-63.

Lai, C.S. (2013). A Study of Computer Project-Based Learning on Electric Circuits for 4th Graders. The Journal of Human Resource and Adult Learning, 9 (1), 55-67.

Manson, E. J. and Bramble, W. J. (1997). Research in education and the behavioral sciences: Concepts and methods. Los Angeles: A Time Mirror Company.

McGrath, D. (2002). Getting started with project based learning. Learning and Leading with Technology, 30 (3), 42-50.

Melograno, V. J. (2006). Professional and student portfolios for physical education. Champaign, IL: Human Kinetics.

Mohsena, B., Abodlvahedb, Z. and Wan, A. (2015). Effect of Project-Based Learning Strategy on Learning Performance of Students with Different Achievement Levels. Asian Journal of Research in Social Sciences and Humanities, 5 (5), 255-264.

Muniandy, B. (2000). An investigation of the use of constructivism and project-based learning. Unpublished Dissertation, University of Oregon.

Özmen, H. (2004). Fen öğretiminde öğrenme teorileri ve teknoloji destekli yapılandırmacı ögrenme. The Turkish Online Journal of Educational Technology, 3 (1).

Simkins, M., Cole, K., Tavalin, F. and Means, B. (2002). Increasing student learning through multimedia projects. Alexandria, VA: Association for Supervision and Curriculum Development.

Summers, E. J. and Dickinson, G. (2012). A longitudinal investigation of project-based instruction and student achievement in high school social studies. Interdisciplinary Journal of Problem-Based Learning, 6 (1), 82-103.

Thomas, J. W. (2000). A review of research on project-based learning. San Rafael, CA: Autodesk Foundation.

Walker, A. and Leary, H. (2009). A problem-based learning meta-analysis: Differences across problem types, implementation types, disciplines and assessment levels. Interdisciplinary Journal of Problem-based Learning, 3(1), 12-43

Wolk, S. (2001). What should we teach? The benefits of exploratory time. Educational Leadership, 59 (2), 56-59.

Yalın, H.İ. (2002). Öğretim teknolojileri ve materyal geliştirme. Ankara: Nobel Yayıncilik. 


\section{Turkish Abstract}

Bilgisayar Destekli Proje Tabanı Öğretim: Fen Başarısında, Bilgisayar Başarısında ve Portfolio Değerlendirmesindeki Etkileri

$\mathrm{Bu}$ çalışmanın amacı bilgisayar destekli proje tabanlı öğretimin öğrencilerin fen-teknoloji ve bilgisayar derslerindeki başarıları ve portfolyo geliştirilmesindeki etkilerini karşılaştırmaktır. Bu amaçla yarı-deneysel desen kullanılmış ve Istanbul Org. Eşref Bitlis İlkokulu yedinci sınıftan 70 öğrenci örneklem olarak seçilmiştir. Öğrenciler kontrol ve deney grubuna rassal olarak atanmıştır. Kontrol grubuna geleneksel proje tabanlı yaklaşımla öğretim yapılırken, deney grubuna ise bilgisayar destekli proje tabanlı öğretim uygulanmıştır. Her iki gruba da yedinci sınıf fen ve teknoloji dersi müfredatından aynı konuyla öğretim yapılmıştır. Beş haftalık öğretim boyunca deney grubundan bilgisayar destekli bir proje hazırlamaları istenirken kontrol grubu sadece proje tabanlı geleneksel metodu kullanmıştır. Çalışmanın sonunda elde edilen bulgular deney grubunun fen ve teknoloji portfolyo puanlarının kontrol grubundan anlamlı bir şekilde daha yüksek olduğunu göstermiştir. Bu sonuç geleneksel metoda göre öğrenim kazanımlarının bilgisayar destekli proje tabanlı öğretimle daha yüksek olduğunu göstermektedir.

Anahtar Kelimeler: proje, proje tabanlı öğretim, bilgisayar destekli proje tabnalı öğretim, portfolyo, Fen ve Teknoloji Dersi

\section{French Abstract}

Ordinateur a aidé Instruction à base de projet : les effets sur Accomplissement de Science, Accomplissement Informatique et Évaluation de Portefeuille

Le but de cette étude est de comparer les effets d'ordinateur ont aidé l'instruction à base de projet sur l'accomplissement des apprenants dans une science et un cours technologique, dans un cours d'informatique et dans le développement de portefeuille. Avec ce but en mémoire, un design(une conception) quasi-expérimental a été utilisé et un échantillon de 70 étudiants de collège d'enseignement général de cinquième(de septième année) d'Org. Esref Bitlis l'École primaire à Istanbul a été choisi. Les étudiants ont été aléatoirement assignés à un des deux groupes : le groupe témoin et le groupe expérimental. L'approche d'apprentissage à base de projet traditionnelle a fourni à l'instruction au groupe témoin, au groupe expérimental a fourni à l'ordinateur a aidé l'approche d'apprentissage à base de projet. On a donné l'instruction aux deux groupes sur le sujet de Nos Conditions de vie dans le programme de 5ème la Science et le cours Technologique. Pendant l'instruction de cinq semaines, le groupe expérimental a été exigé pour préparer les projets avec l'utilisation de la méthode de projet, tandis que le groupe témoin a utilisé la méthode à base de projet traditionnelle. À la fin de l'étude, les découvertes ont révélé que la science et la technologie et l'évaluation de portefeuille beaucoup le groupe expérimental étaient significativement plus hauts que celui du groupe témoin. Ce résultat indique que les gains apprenants sont plus hauts quand l'ordinateur fournit à l'instruction a aidé l'instruction à base de projet que par la méthode traditionnelle.

Mots clés: l'instruction de projet, à base de projet, l'ordinateur a aidé l'instruction à base de projet, le portefeuille, la Science et des Cours Technologiques 


\section{Arabic Abstract}

التدريس القائم على المشاريع العملية بمساعدة الحاسوب :آثار على التحصيل العلمي، الإنجاز الحاسوب وتقييم المحفظة

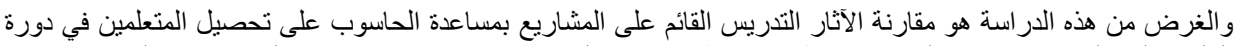

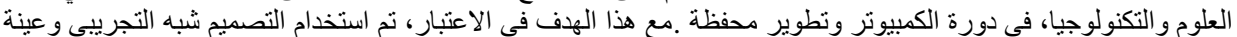

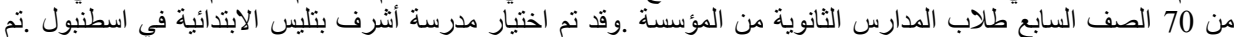

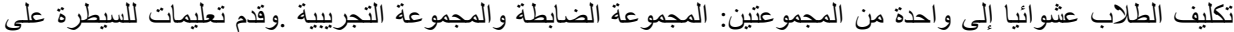

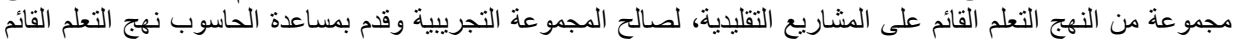

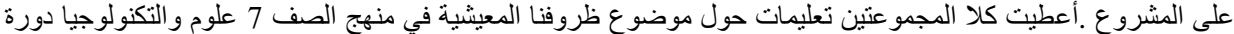

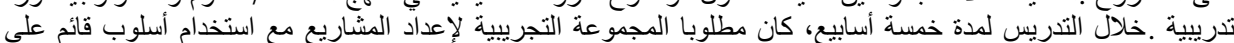

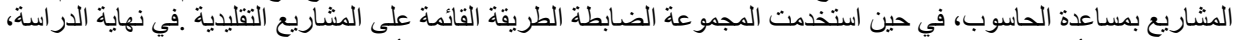

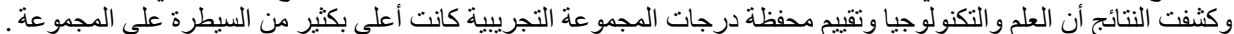

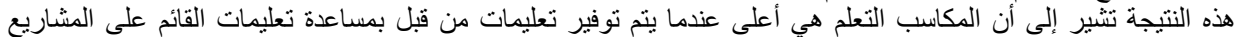
الكمبيوتر من الطريقة التقليدية.

الكلمات الرئيسية: مشروع و التعليم القائم على المشاريع، بمساعدة التندريس القائم على المشاريع الكمبيوتر، محفظة و العلوم 